\title{
Ammonia Removal Using Coconut Shell Based Adsorbent: Effect of Carbonization Duration and Contact Time
}

\author{
Nur Indradewi Oktavitri*, Hery Purnobasuki, Eko Prasetyo Kuncoro, Indah Purnamasari \\ Department of Biology \\ Faculty of Science and Technology, Airlangga University, Indonesia \\ *Corresponding author: nur_i_d_o@yahoo.com
}

\begin{abstract}
The preparation of adsorbent using activated coconut shell was investigated at carbonization duration and adsorption contact time. The coconut shell was activated using physical and chemical activation. This research focused on variation of physical activation such as carbonization. The carbonization had two steps, there are high temperature and medium temperature. This research used $500^{\circ} \mathrm{C}$ at high temperature and $220^{\circ} \mathrm{C}$ at medium temperature. The duration of medium temperature was varied in 1,2 , and 4 hours. The chemical activation used $\mathrm{H}_{3} \mathrm{PO}_{4}$. The ammonia concentration of simulated wastewater around $6000 \mathrm{mg} / \mathrm{l}$. The acclimatization period was $8 \mathrm{~d}$. The coconut shell ability for ammonia removal was observed after acclimatization period in $0,2,4,6$, and 8d. The effect of carbonization period and contact time on ammonia adsorption of dairy simulated wastewater was discussed in this research. This research used anaerobic digestion with 10 liter of volume. The concentration of ammonia was measured with nessler methods. Carbonization duration and contact time increased the adsorption capacity. From the obtained result of adsorption isotherm, the Langmuir equation was the best fit for all carbonization period, especially 4-hour carbonization period.
\end{abstract}

Keywords: activated carbon, adsorption, anaerobic digestion, ammonia removal, carbonization, contact time

\section{Introduction}

High strength of ammonia is the effluent characteristic of agro/food industry industry [1], [2]. The high ammonia concentration causes stress in environment, therefore the industrial effluent should be managed. Anaerobic digestion is widely used to treat industrial wastewater because of low cost, low sludge production and energy saving [3]. The anaerobic digestion has three main steps process, i.e. acidogenesis, acetogenesis, and methanogenesis. The indicator of successful process of anaerobic digestion is limitation of inhibitor of those processes. High concentration of ammonia, heavy metal, unstable $\mathrm{pH}$ are problems of anaerobic process [4], [5]. The fail of the process is usually caused by the existence of high value of ammonia.

Ammonia is produced from wastewater and it is resulted from degradation of organic substance from anaerobic process [6]. Therefore, the ammonia concentration increases potentially during anaerobic process. The parameter indicates the amount of ammonia is Total Ammonia Nitrogen. The total Ammonia Nitrogen consist of ammonium ion and free ammonia. The ammonium ion interacts with membrane cell of microorganism [4]. It causes decreasing of microorganism population. Methanogene bacteria is the genus of bacteria intolerant with high ammonia concentration.

There are many ammonia removal technologies, such as chemical precipitation, air stripping, nitrification, and denitrification, anaerobic ammonium oxidation, short-cut nitrification and combination of those process [7]. However, those processes require complex process and expensive operation and maintenance. The adsorption is effective methods for removal ammonia [8]. There are several kind of adsorbents, such as activated carbon coconut shell [8]; clay [9], and zeolite [10]-[12]. Activated carbon is recommended by [13] to adsorb pollutant. In order to make competitive adsorbent, activated carbon from nature such as coconut shell is suggested by Boopathy et al [8]. 
In order to enhance the adsorption capability of adsorbent, the activation process is recommended for it [14], [15]. The physic activation with high temperature influences the pores characteristic of adsorbent [16]. In addition, Legrauri et al [17] informed that variation of activated time in high temperature give different response of adsorbent to remove pollutant. In addition, the ability of adsorbent gives real performance in several contact time.

This research aims to evaluate the adsorption capacity of activated carbon from coconut shell with variation of carbonization periods. The result of the experiment is fitted to the adsorption capacity of activated coconut shell using Freundlich and Langmuir as famous isotherm model. Isotherm model is used to evaluate adsorption capacity of ammonia using activated coconut shell, Therefore, the model can be applied in industry scale [18].

\section{Materials and Methods}

\subsection{Preparation of Adsorbent from Activated coconut shell}

This research used fine powder of coconut shell char to got optimized adsorption process from the Coconut shell char [19]. The coconut shell char was activated using physical and chemical activation. The activation process enhanced the ability of coconut shell char to adsorb the contaminant [15]. Before the activation step, the fine coconut shell char was rinse using tap water. At physical activation step (carbonization periods), coconut shell char was dried at $220^{\circ} \mathrm{C}$ using oven (Memmert series 100-800) [8]. The activation process enhanced surface area ofactivated coconut shell [20]. The variable for carbonization period used were 1,2 , and 4 hours in $220^{\circ} \mathrm{C}$. The activated coconut shell was contacted with $\mathrm{H}_{3} \mathrm{PO}_{4} 10 \%$ for chemical activation.

\subsection{Dairy simulated waste water}

This research used dairy simulated wastewater. Dairy simulated wastewater consists of $\mathrm{NH}_{4} \mathrm{Cl}, 1 \mathrm{~g}$ $\mathrm{KH}_{2} \mathrm{PO}_{4} ; 0,05 \mathrm{MgSO}_{4} .7 \mathrm{H}_{2} \mathrm{O} ; 0,038 \mathrm{~g} \mathrm{CaCl}_{2} ; 2$ g NaHCO 3 for 1 litre of simulated waste water [21]. The ammonia concentration of dairy simulated wastewater was $6000 \mathrm{mg} / \mathrm{l}$. The substrate feed as inoculums for anaerobic process was collected from Pegirian Slaughter House, Surabaya, Indonesia. The substrate was added to wastewater was $1 / 100(\mathrm{v} / \mathrm{v})$.

\subsection{Design of reactor}

Three batch reactors from Low Density Polyethylene (LDPE) were operated in this research for 15 days. Total volume of reactor was $12 \mathrm{~L}$. The $10 \mathrm{~L}$ simulated waste water was added to the reactor and total activated coconut shell was added $200 \mathrm{~g}$. The sampling port at $13 \mathrm{~cm}$ of height reactor. The illustration of reactor was figured out at Figure 1. The performance of every reactor was measured using Total Ammonia Nitrogen (TAN). The monitoring of adsorption process will be held in $8 \mathrm{~d}$ after acclimation. The acclimation need $8 \mathrm{~d}$. The reactors were monitored every 2 days.

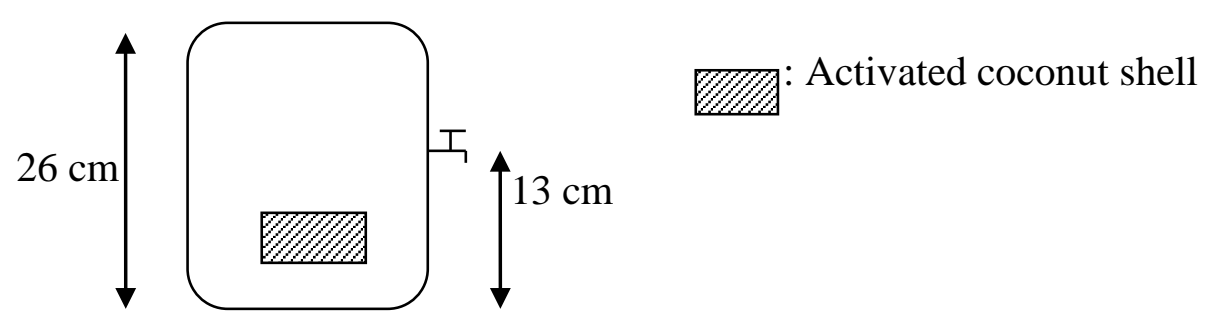

Figure 1 Schematic of Reactor

\subsection{Analytical methods}


Total Ammonia Nitrogen (TAN) with nessler methods was analysis based on Standard Methods [22].

\section{Results and Discussion}

\subsection{Effect of Carbonization Period}

The carbonization step was part of activation process. The activation step increased the pore size of media. Boopathy et al [8] informed that the pore size after 1-hour activation reached $20 \mu \mathrm{m}$. The effect of carbonization duration to adsorption capacity was appeared in Figure 2. The equation to measured adsorption capacity using Equation (1). The increasing of carbonization period enhanced the adsorption capacity. It possibly caused by long duration of carbonization enhanced the pores size of coconut shell.

$q_{e}=\frac{\left(c_{0}-c_{e}\right) V}{m}$

Where:

Co, Ce, qe as TAN concentration at $\mathrm{t}=0$; as TAN concentration after adsorption process; as adsorption capacity at equilibrium, respectively.

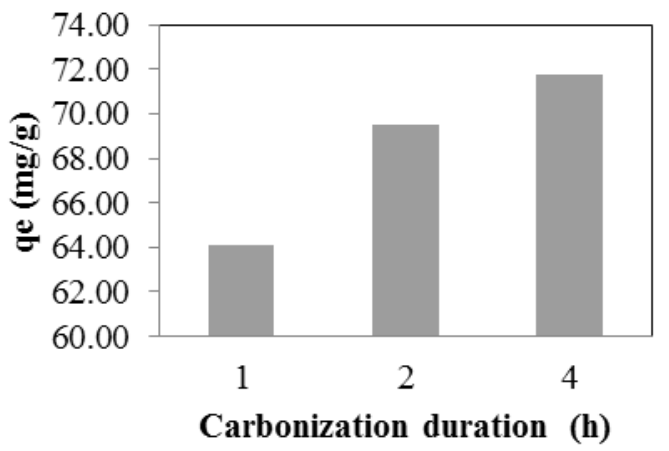

Figure 2 Effect of carbonization duration to adsorption capacity

\subsection{Effect of Contact Time}

The effect of contact time on adsorption capacity was described in figure 3. The adsorbent was carbonized in $220^{\circ} \mathrm{C}$ for 1 hour and contacted with simulated wastewater for 2, 4, 6, and 8 days. In The adsorption capacity of ammonium (qe) increased significantly in 8 days observation. It indicated that the Coconut shell sites unsaturated after 8 days observation and potentially adsorbed ammonia more than 8 days. The research of Kučič [23] presented that the adsorbent saturated in certain time if the qe line in graph in stationer position.




Figure 3. Effect of contact time to adsorption capacity

\subsection{Adsorption Isotherm}

The adsorption process described with adsorption isotherms [24]. The capability of adsorbent for removing pollutant under certain condition was provided with isotherm equation. The amount of exchanged ion by coconut shell when equilibrium concentration was described in ion-exchange isotherm [25]. The Freundlich and Langmuir models were used to evaluated adsorption model of ammonia in several contact time. The freundlich equation was described in Equation (2).

$$
q_{\theta}=K_{F} \cdot C_{\theta}^{\frac{1}{n}}
$$

Where: $\mathrm{K}_{\mathrm{F}}$ (as Freundlich indicator of adsorption capacity) and $1 / n$ (is the adsorption intensity). The logarithmic form of Freundlich Equation (3) [10], [23].

$$
\log q_{e}=\log K_{F}+\frac{1}{n} \log C_{e}
$$

where values of $K F$ and $n$ are calculated from the intercept and slope of the plot.

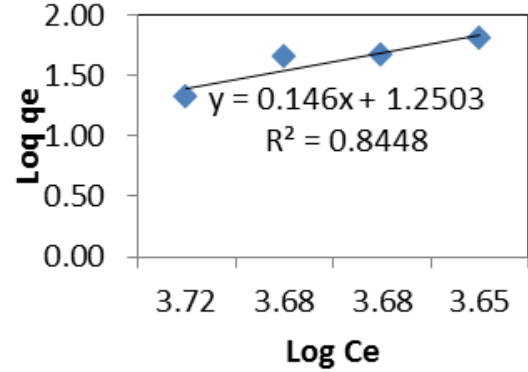

1 hour activation (M1)

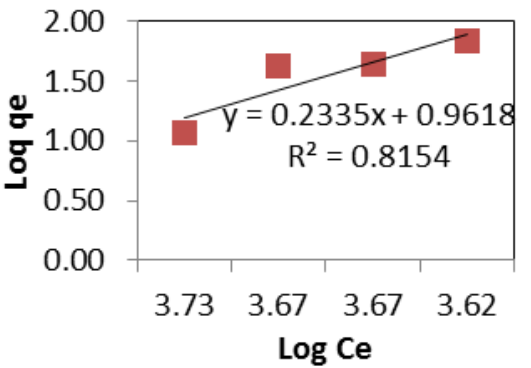

(b) 2 hours activation (M2)

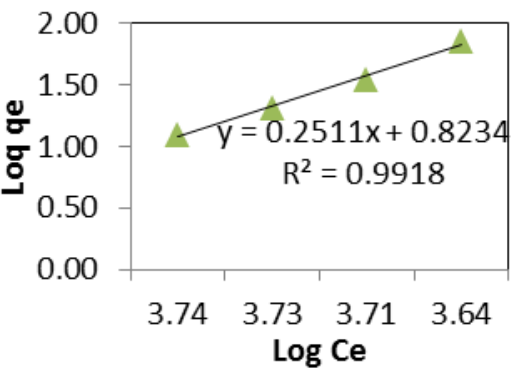

(c) 4 hours activation (M4)

Figure 4 Freundlich Isotherm with Different Activation Time

Figure 4 described linear regression equation of Freundlich Isotherm which $y$ was Loq qe, logarithmic of adsorption capacity from each activation time. The different equation implicated to difference slope and intercept of those equation. It was caused by different treatment for adsorbant [26]. The slope from linear regression, $1 / \mathrm{n}$ value, indicated of the favorability of adsorption. $\mathrm{n}$ values from three different activation time was $n<1$ (Table 1). The $1 / \mathrm{n}$ value around 0,1 and 0,5 easily to adsorb; and more than 2 is hard to adsorb [12]. The experimental results indicated that complexity of wastewater simulation characteristic made activated coconut shell unfavorable to adsorb ammonia. The $\mathrm{R}^{2}$ of coconut shell with 4-hour activation closest to 1 indicated that it more suitable to Freundlich Isotherm than 1 and 2 hours activation.

The Langmuir equation was another famous isotherm model. The difference between Freundlich and Langmuir were assumption of adsorption layer. The Langmuir theory assumed monolayer coverage of adsorbate over a homogenous adsorbent surface [23]. A basic assumption is that all adsorption sites are equivalent and adsorption on active sites is independent of whether the adjacent is occupied [12]. The Langmuir equation in Equation (4) and (5) [27]. 


$$
\mathrm{q}_{\mathrm{e}}=\frac{\mathrm{K}_{\mathrm{L}} \cdot \mathrm{C}_{\mathrm{e}}}{\left(1+\mathrm{b} \cdot \mathrm{C}_{\mathrm{e}}\right)}
$$

And linear equation was:

$$
\frac{\mathrm{C}_{\mathrm{e}}}{\mathrm{q}_{\mathrm{e}}}=\frac{1}{\mathrm{~b} \cdot \mathrm{K}_{\mathrm{L}}}+\frac{1}{\mathrm{~b}} \mathrm{C}_{\mathrm{e}}
$$

Where $K \mathrm{~L}$ is the Langmuir adsorption constant related to the energy of adsorption $(1 / \mathrm{mg})$ and $b$ is the mono-layer adsorption capacity of adsorbent (mg NH4+-N/g). Therefore, a plot of $\gamma \mathrm{e} / \mathrm{qe}$ versus $\gamma \mathrm{e}$ gives a straight line of slope $1 / b$ and intercept $1 /(b \cdot K L)$ (Figure 5).

The values of $K F, K L, n, b$ and $\mathrm{R}^{2}$ for different activation time of coconut shell, are given in Table 1 . Figure 5 also indicated that different equation and $\mathrm{R}^{2}$ for different activation time. It also indicated that 1hour activation was the best fit equation with $\mathrm{R}^{2}$ closest to 1 (Table 1 ). It was suitable with Langmuir equation.

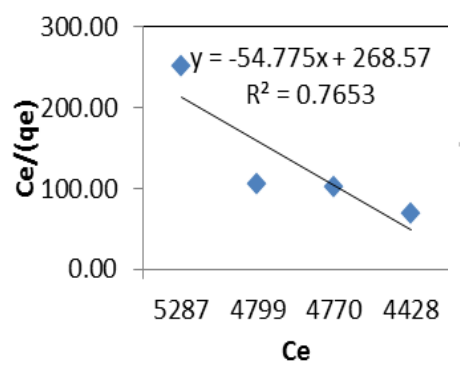

1 hour activation (M1)

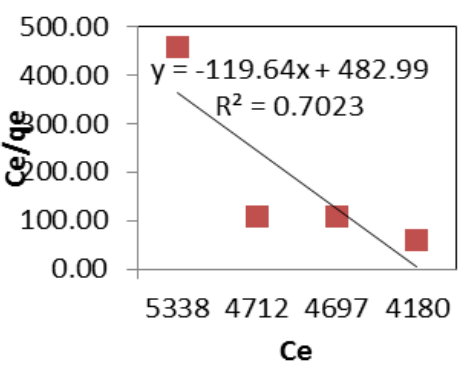

(b) 2 hours activation (M2)

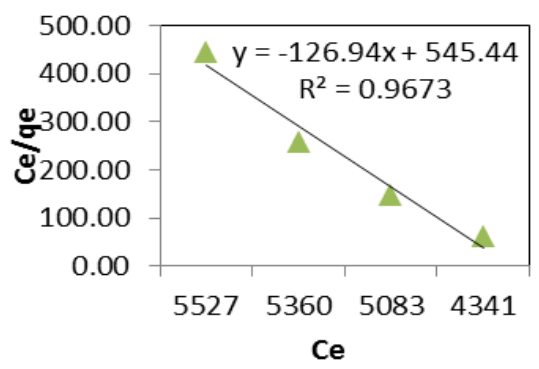

(c) 4 hours activation (M4)

Figure 5 Linear Equation of Langmui Isotherm with Different Activation Time

Table 1 described adsorption properties described how pollutant interact with adsorbent. Comparison between Freundlich and Langmuir to activation time of coconut shell presented that ammonia adsorption have similar pattern for both of them. It described that both of model have ability to figured out every mass of adsorbent to remove pollutant in concentration equilibrium of adsorbat [28].

The Freundlich and Langmuir have different assumption. The freundlich adsorption assumed that the adsorption capacity was not monolayer and surface area was heterogeneity [29], [30]. The langmuir adsorption isotherm assumed that adsorption one sites did not affect to another sites. It was caused all surface have homogenous and has similar adsorbate affinity [31].

The carbonization period and contact increased the adsorption capacity. The adsorption isotherm for carbonization period best fitted with Langmuir Equation. It indicated that the surface area of activated coconut shell was homogeny and multilayer.

Table 1 The values of $K F, K L, n, b$ and $R^{2}$

\begin{tabular}{lllll}
\hline Isotherm Equation & Component & M1-6000 & M2-6000 & M4-6000 \\
\hline Freundlich Isotherm & Slope $(1 / \mathrm{n}):$ & 0,146 & 0,233 & 0,251 \\
& n: & 6,84932 & 4,291845494 & 3,98406 \\
& Intercept $\left(\log \mathrm{K}_{\mathrm{F}}\right):$ & 1,25 & 0,961 & 0,823
\end{tabular}




\begin{tabular}{lllll} 
& $\mathrm{K}_{\mathrm{F}}:$ & 17,7828 & 9,141132415 & 6,65273 \\
& $\mathrm{R}^{2}:$ & 0,844 & 0,815 & 0,991 \\
\hline Langmuir Isotherm & & $\mathrm{M} 1-6000$ & $\mathrm{M} 2-6000$ & $\mathrm{M} 4-6000$ \\
& Slope (1/b): & $-54,77$ & $-119,6$ & $-126,9$ \\
& $\mathrm{~b}:$ & $-0,0183$ & $-0,0083612$ & $-0,0079$ \\
& Intercept (1/b.K $\left.\mathrm{K}_{\mathrm{L}}\right):$ & 268,5 & 482,9 & 545,4 \\
& $\mathrm{~K}_{\mathrm{L}}:$ & $-0,204$ & $-0,24767033$ & $-0,2327$ \\
& $\mathrm{R}^{2}:$ & 0,765 & 0,702 & 0,967 \\
\hline
\end{tabular}

\section{Acknowledgment}

This research is part of research grant which sponsored by DIPA Ditlitabmas 2015 Number: 519/UN3/2015,26 March 2015.

\section{Reference}

[1] M. Altinbas, I. Ozturk, and A. F. Aydin, "Ammonia recovery from high strength agro industry effluents.," Water Sci. Technol., vol. 45, no. 12, pp. 189-95, 2002.

[2] R. Rajagopal, D. I. Massé, and G. Singh, "A critical review on inhibition of anaerobic digestion process by excess ammonia,” Bioresour. Technol., vol. 143, pp. 632-641, 2013.

[3] M. Jawed and V. Tare, "Post-mortem examination and analysis of anaerobic filters," Bioresour. Technol., vol. 72, no. 1, pp. 75-84, Mar. 2000.

[4] M. H. Gerardi, The Microbiology of Anaerobic Digesters. Hoboken, NJ, USA: John Wiley \& Sons, Inc., 2003.

[5] Indriyati, "Unjuk Kerja Reaktor Anaerob Lekat Diam Terendam Dengan Media Penyangga Potongan Bambu," J. Tek. Lingkung., vol. 8, no. 3, pp. 217-222, 2007.

[6] C. Chernicharo, Anaerobic Reactors. 2007.

[7] Y. H. Ahn, "Sustainable nitrogen elimination biotechnologies: A review," Process Biochem., vol. 41, no. 8, pp. 1709-1721, 2006.

[8] R. Boopathy, S. Karthikeyan, A. B. Mandal, and G. Sekaran, "Adsorption of ammonium ion by coconut shellactivated carbon from aqueous solution: kinetic, isotherm, and thermodynamic studies," Environ. Sci. Pollut. Res., vol. 20, no. 1, pp. 533-542, Jan. 2013.

[9] M. Seredych, A. V. Tamashausky, and T. J. Bandosza, "Surface features of exfoliated graphite/bentonite composites and their importance for ammonia adsorption,” Carbon N. Y., vol. 46, no. 9, pp. 1241-1252, Aug. 2008.

[10] A. Abdul Halim, H. Abdul Aziz, M. Azmi Megat Johari, and K. Shah Ariffin, "Comparison study of ammonia and COD adsorption on zeolite, activated carbon and composite materials in landfill leachate treatment," Desalination, vol. 262, pp. 31-35, 2010.

[11] L. Zhou and C. E. Boyd, "Total ammonia nitrogen removal from aqueous solutions by the natural zeolite, mordenite: A laboratory test and experimental study,” Aquaculture, vol. 432, pp. 252-257, 2014.

[12] J. Wang, W. Jin, H. Guo, X. Wang, and J. Liu, "Experimental Study on Ammonia Nitrogen Adsorption Performance of Zeolite Powder,” Chem. Eng. Trans., vol. 46, pp. 79-84, 2015.

[13] F. Çeçen and Ö. Aktaş, Activated Carbon for Water and Wastewater Treatment. Weinheim, Germany: WileyVCH Verlag GmbH \& Co. KGaA, 2011.

[14] Y. Meisrilestari, R. Khomaini, and H. Wijayanti, "Pembuatan Arang Aktif dari Cangkang Kelapa Sawit dengan Aktivasi Secara Fisika, Kimia dan Fisika dan Kimia,” Konversi, vol. 2, no. 1, pp. 45-50, Apr. 2013.

[15] Y. Guo and D. A. Rockstraw, "Physicochemical properties of carbons prepared from pecan shell by phosphoric acid activation,” Bioresour. Technol., vol. 98, no. 8, pp. 1513-1521, May 2007.

[16] J. Katesa, S. Junpiromand, and C. Tangsathitkulchai, "Effect of Carbonization Temperature On Properties of Char And Activated Carbon From Coconut Shell,” Suranaree J. Sci. Technol., vol. 20, no. 4, pp. 269-278, 2013.

[17] K. Legrouri et al., "Characterization and evaluation performance of activated carbon prepared from coconut shell argan,” J. Chem. Pharm. Res., vol. 4, no. 12, pp. 5081-5088, 2012.

[18] M. Aqeel Ashraf, K. Mahmood, A. Wajid, M. Jamil Maah, and I. Yusoff, "Study of low cost biosorbent for biosorption of heavy metals," in International Conference on Food Engineering and Biotechnology, 2011, pp. $60-68$. 
[19] Y. B. Seok et al., "The investigation on the potential of coconut shell powder composite in term of carbon composition, surface porosity and dielectric properties as a microwave absorbing material,” EnvironmentAsia, vol. 9, no. 1, pp. 9-17, 2016.

[20] M. Song et al., "The comparison of two activation techniques to prepare activated carbon from corn cob," Biomass and Bioenergy, vol. 48, pp. 250-256, 2013.

[21] A. T. Dawood, A. Kumar, and S. S. Sambi, "Study on Anaerobic Treatment of Synthetic Milk Wastewater under Variable Experimental Conditions,” Int. J. Environ. Sci. Dev., vol. 2, no. 1, pp. 17-23, 2011.

[22] APHA (American Public Health Association), Standard Methods for Examination of Water \&amp; Wastewater (Standard Methods for the Examination of Water and Wastewater), 20th ed. New York: American Public Health Association, 1999.

[23] D. Kučić, M. Markić, and F. Briški, “Ammonium Adsorption On Natural Zeolite (Clipnoptilolite): Adsorption Isotherms and Kinetics Modeling,” Ammonium Adsorpt. Nat. Zeolite Adsorpt. Holist. Approach to Environ., vol. 24, pp. 145-158, 2012.

[24] S. Liang, X. Guo, N. Feng, and Q. Tian, "Isotherms, kinetics and thermodynamic studies of adsorption of Cu2+ from aqueous solutions by Mg2+/K+ type orange peel adsorbents,” J. Hazard. Mater., vol. 174, no. 1-3, pp. 756-762, Feb. 2010.

[25] H. Huang, X. Xiao, B. Yan, and L. Yang, “Ammonium removal from aqueous solutions by using natural Chinese (Chende) zeolite as adsorbent,” J. Hazard. Mater., vol. 175, pp. 247-252, 2010.

[26] M. Handayani and E. Sulistiyono, "Model Kinetika Langmuir Untuk Adsorpsi Timbal Pada Abu Sekam Padi,” in Seminar Nasional Sains dan Teknologi Nuklir PTNBR - BATAN, 2009, pp. 130-136.

[27] B. S. T. Sembodo, "Model Kinetika Langmuir Untuk Adsorpsi Timbal Pada Abu Sekam Padi,” Ekuilibriu, vol. 5, no. 1, pp. 28-33, 2006.

[28] M. H. Kalavathy, T. Karthikeyan, S. Rajgopal, and L. R. Miranda, "Kinetic and isotherm studies of Cu(II) adsorption onto H3PO4-activated rubber wood sawdust,” J. Colloid Interface Sci., vol. 292, no. 2, pp. 354-362, Dec. 2005.

[29] A. A. Halim, N. N. Z. Abidin, N. Awang, A. Ithnin, M. S. Othman, and M. I. Wahab, “Ammonia and COD removal from synthetic leachate using rice husk composite adsorbent,” J. Urban Environ. Eng., vol. 5, no. 1, pp. 24-31, 2011.

[30] M. Ghauri, M. Tahir, T. Abbas, and M. Shehzad Khurram, “Adsorption Studies for The Removal of Ammonia By Thermally Activated Carbon,” Sci.Int.(Lahore), vol. 24, no. 4, pp. 411-414, 2012.

[31] D. Mohan and C. U. Pittman Jr., "Activated carbons and low cost adsorbents for remediation of tri- and hexavalent chromium from water,” J. Hazard. Mater., vol. 137, no. 2, pp. 762-811, Sep. 2006. 